\title{
Institutional Experimentation, Directed Devolution and the Search for Policy Innovation
}

Transformations in the world of work have led to policy and institutional experimentation by many actors, including unions, unorganized workers, employers and policy-makers (Minter, 2017; Stewart \& Stanford, 2017; Wright et al., 2019). This article is most relevant to part of the last group - those policy-makers who are sympathetic to workers' needsand, by implication, it is relevant to unions and worker bodies that are trying to get good policy developed. This paper proposes an institutional arrangement, referred to as "directed devolution," rather than a specific policy. Directed devolution is a form of multilevel policy-making, that is, it is implemented at more than one level of government. "Directed devolution" means that legal entitlements or obligations are first set at a higher (say, national) level, after which a lower level is required to determine detailed implementation of the standard set by the higher-level policy, in order to protect the affected workers' interests.

In this article we propose some general principles for institutional interventions in digitally disrupted work, using the example of the platform economy. We start with the background on how we got to this situation, including an exposition of disruption and institutional experimentation and the situation in the platform economy itself, before discussing directed devolution in more detail. In that discussion we will see the example of New York passenger transport, consider different forms of multi-level regulation, discuss some criteria for using 
directed devolution and then return to elaborate on how the principle of directed devolution can be applied in the platform economy, before concluding.

\section{Disruption and Institutional Experimentation}

Over the past three decades corporations have sought to minimize their costs, risks and accountability while maximizing control, within a general model that can be called "notthere employment" (Peetz, 2019). The focal point for public attention has been the "platform economy" (De Stefano, 2016), but the general problem of transferral of risk and income alongside shifting accountability and control is widespread. "Not-there" employment takes different forms in different industries; for example, the growth of franchising in retailing (Weil, 2014), of labour hire in mining and manufacturing (Forsyth, 2016), of temporary or casual employment in education (May, 2014), of subcontracting in food services (Rees \& Fielder, 1992) and of platform work in passenger transport and food delivery (Rosenblat \& Stark, 2016; Veen, Barratt, \& Goods, 2019). While institutional contexts vary (Kalleberg, 2018), the common feature is that contracts enable the core corporation to maintain control, but the costs of and accountability for labour conditions are outsourced away from the core corporation to some peripheral entity. One outcome has been the decline of the pre-existing "web of rules" that governed employment relations (Wright et al. (2019) referring to Kerr and Siegal (1955) and Dunlop (1958)). This transformation has led to the rise of a "patchwork of rules" in place of the "web of rules" (Wright et al., 2019), but this patchwork lacks consistency for efficient transmission of 
knowledge. In a context of weakening protections, work has become more insecure (Kalleberg, 2018).

The concept of "disruption" is particularly salient here. Modern usage of the term originated with the work of Clayton Christensen (1997) in analyzing "disruption" in markets. When a dominant firm in an industry was dethroned by a new competitor with an innovative technological base that appealed to consumers, disruption was said to occur. Hence Blockbuster, once dominant in video rental, was said to be disrupted and subsequently forced into bankruptcy by the Netflix subscription model that eventually went online. Eastman Kodak, dominant in cameras and film, was disrupted by digital cameras, especially in phones, and shrank to near insignificance. Most recently, "Uberization," i.e., the introduction of digital technology platforms ranging from passenger carriage to home care, is seen as disrupting many markets. The term "disruption" has become popular and has covered so many situations it has almost lost its meaning, though more recently Gans (2016) has sought to reclaim the expression by specifying disruption as occurring when a dominant firm loses its position to a new rival even though it is perfectly logical for the dominant firm to continue doing what it did before (so disruption is not, for example, due to the dominant firm being "slow-moving").

To deal with disruption, policy-makers have come up with a variety of solutions that are inadequate, contradictory or confused. Globalization “opened up policy space for experimentation[s] in...employment regulation" (Stone, 2015), only some of which achieved 
their aims. Policies relying on various forms of market mechanisms often failed to meet their objectives, frequently delivering the greatest benefits to those already with the most resources, and away from those with fewer resources-the ones that may have been targeted by the policy (Quiggin, 2010). The phrase "wicked problems" emerged to describe policy problems that seem almost intractable to policy-makers due to their complexity, multiple stakeholders and conflicting solutions (Head, 2008). Powerful interest groups have been able to mutilate or corrupt the policy process, using extensive resources to "buy" support and minimize opposition (Borkholder, Montgomery, Chen, \& Smith, 2018; Holmes, Cary, Yerardi, \& Zubak-Skees, 2019), a phenomenon reflecting the strong power of capital over the state in capitalism (Poulantzas, 1980). Moreover, even on those infrequent occasions when labour interests, through electoral politics, come to dominate the state, policy is difficult and full of contradictions, competing interests and problems of implementation, with no single objective that can be optimized with a sufficiently informed algorithm (Pressman \& Wildavsky, 1973).

The emergence of the modern era of globalization, neoliberal policy and financialization has been characterized by the employer's search for "flexibility" to deal with the uncertainty that managers encounter (Streeck, 1987). The corresponding response has been experimentation: the flexible way in which union and state actors can react to an uncertain environment and prospects, due in no small part to actions by corporations.

A common form has been "organizational experimentation," whereby organizations attempt to change the way they are structured, linked to or perceived by others or to 
change the way others understand work (Murray, Levesque, Morgan, \& Roby, 2020, p. 137). More ambitiously, they may attempt "institutional experimentation," that is, changing the institutions themselves, and how they relate to organizations and the widespread norms that shape understanding of work (Murray et al., 2020, p. 137). New institutional arrangements and inter-organizational learning by policy-makers have been recognized as a key element in overcoming "wicked problems" in policy (Ferlie, FitzGerald, Dopson, McGivern, \& Bennett, 2011). The specific examples given by Murray et al. (2020)-coworking spaces and new forms of collective representation-are experiments by non-state actors, while in this article we focus on state actors by asking: What form of institutional arrangement can best enable the lessons of policy experimentation to be learned and disseminated? We are thus seeking a specific form of institutional experiment to address, not a specific local issue, but rather a diversity of issues with their appropriate responses and the incorporation into broader policy processes of the experiments that respond to those issues.

\section{The Platform Economy}

Of all the areas that relate to work, perhaps the most visible one to experience disruption is the platform or "gig" economy (De Stefano, 2018; Woodcock \& Graham, 2020). It is not the only one-for example, human resource management activities, such as recruitment, selection and employee monitoring, are being disrupted by artificial intelligence (O'Neill, 2016), and throughout the labour market many jobs are seen as threatened by automation 
or other new digital technologies (Arntz, Gregory, \& Zierahn, 2016; Frey \& Osborne, 2013). But the platform economy is notable for how digital technologies are creating new modes of "algorithmic" management and for the apparent replacement of employment with contractual relationships (Stewart \& Stanford, 2017; Wood, Graham, Lehdonvirta, \& Hjorth, 2018), much like in the piecework of centuries past (Alkhatib, Bernstein, \& Levi, 2017). Digital apps enable workers to be classified by firms as contractors rather than as employees, and core corporations can exercise control while working around the minimum employment standards that legislators impose, as they do not operate under conventional hourly wage models (Dubal, 2019b).

The "platform economy" is a broad term that covers very diverse experiences, including some "high end" work (mostly situations where workers have considerable autonomy and control), and "low end" work where much power rests with the organizations that control the platforms (Wood et al., 2018; Woodcock \& Graham, 2020). Most policy concerns relate to the lower end, including low pay (with many workers receiving pay below the equivalent of the minimum wage in their jurisdiction), lack of health and safety protections, poor or no access to injury compensation, underemployment, income and employment insecurity, lack of training and career development and little practical discretion in the face of algorithmic management (Berg, 2016; Chartered Institute of Personnel and Development, 2017; Lepanjuuri, Wishart, \& Cornick, 2018; Peetz, 2018; Smith, 2016; Unions New South Wales, 2016; Wood et al., 2018). Many of these concerns come about because classifying platform economy workers as contractors deprives them of most protections of employment law. Resistance is growing but locational fragmentation of workers and contractor status makes 
organizing platform workers difficult, but not impossible (Johnston \& Land-Kazlauskas, 2018; Woodcock \& Graham, 2020), and a variety of innovative responses (e.g., worker cooperatives) have arisen (Scholz \& Schneider, 2017). A series of potential public policy approaches were examined in the Australian context by Stewart and Stanford (2017), including clarifying or expanding definitions of "employment," creating a new category of "independent worker," creating rights for "workers" rather than for employees and reconsidering the concept of "employer." In addition, Forsyth (2020) focuses on the key issue: whether gig economy workers are employees or contractors.

Meanwhile, app technology enables capital to find new ways to control the labour process, there are unclear or inconsistent indications from governments and courts on workers' employment status, and many firms and many workers insist on the benefits of flexibility for workers. Probably nowhere has the difficulty of making policy been more evident than in those areas newly infiltrated by digital technology (Meil \& Kirov, 2017), though other factors in the rise of the platform economy have included consumer behaviour and globalization (Woodcock \& Graham, 2020). Digital technology has brought about rapid changes in the relative market power of groups, individuals or corporations, and often made redundant policy measures that have been painstakingly introduced. Policy-makers have been slow to adjust, exhibiting confusion as to what should be done (Veen et al., 2019). There have been various attempts to regulate the gig economy or at least to regulate some aspects of itthrough judicial regulation (by courts or tribunals) or executive regulation (through legislation or executive fiat). No clear, consistent direction has emerged. 
An example of how policy-makers have responded is in the July 2020 Report of the Inquiry into the Victorian On-Demand Workforce, in Australia's second-largest state (James, 2020). Its authors identified many of the problems described above and came up with "balanced" proposals they described as "revisionist, not revolutionary" (ibid p. 188). The key recommendation was to "clarify the work status test including by adopting the 'entrepreneurial worker' approach, so that those who work as part of another's enterprise or business are 'employees' and autonomous, 'self-employed' small business workers are covered by commercial laws" (ibid. p. 193). Crucial to whether this recommendation would make any difference is how directive any resultant legislation would be. Allowing courts or tribunals substantial discretion could well lead to little change from the status quo, especially as platform firms claim to be facilitating entrepreneurship (Dubal, 2019a; Stewart \& McCrystal, 2019). At the time of writing, it was unclear what legislation would follow. But even with highly directive legislation, labour protections would remain unavailable to whichever workers were still ultimately defined as not being employees.

One, perhaps more ambitious, legislative experiment was the passage of the AB5 legislation in California, which defined whether certain workers were employees or independent contractors. It followed the precedent set by a state Supreme Court decision (the Dynamex decision) (Dubal, 2019a). There are multitudinous other policy experiments from which others can learn. For example, when an inquiry into the regulation of workers' compensation (injury insurance) in Queensland, Australia (Peetz, 2018) examined such compensation in the gig economy, the inquiry report included a proposal that coverage at certain types of firms should not rely on answering the vexed question as to whether gig 
workers are employees or independent contractors, but the proposal was not so readily extendable to other conditions of employment. Another policy experiment is the regulation of New York passenger transport, discussed below. There are many more. What stands out is the diversity of circumstances and the diversity of approaches to regulation of the platform economy and, more broadly, to fragmentation of the world of work. There are a range of approaches to regulation, as well as experiments. Policy-makers need to know not only how to collect and summarize the lessons from those experiments but also how to put them into practice. That process needs, in turn, to take into account the diversity of circumstances and situations affecting vulnerable workers, while protecting the most vulnerable.

\section{Directed Devolution}

Under directed devolution, the legal entitlements or obligations would be set at a higher level (say, a national jurisdiction), and a lower level would be required to work out the detailed implementation of the standards that are set forth in higher-level policy, with a view to protecting the affected workers' interests. For example, after a legislative or executive body (a "policy framer") determines the nature of the problem and the structure to be established, a specially established national body (the "lead agency") may set a minimum hourly wage. Then, where it is not immediately obvious how an hourly wage rate may apply, a series of subsidiary bodies (the "agencies of detail") might separately 
determine how the minimum wage should be calculated for specified circumstances (e.g., for a specific industry). Hourly wage rates might be easily identifiable for the vast majority of workers - those in an established employment relationship-but less obviously for workers in "rideshare," food delivery or elsewhere in the platform economy. The subsidiary bodies might cover specific industries or groups of industries. There may, for instance, be one for passenger road transport ("rideshare" and taxi drivers). There might be another for food delivery, and so on. The subsidiary bodies may need to be quite innovative in how they determine the equivalent of a minimum wage. The calculation of minimum rates for passenger transport operators in New York, discussed below, provides an illustration of how innovative they may need to be. The subsidiary body would be legally obligated to come up with a method to determine a minimum rate of payment that most closely approximates the nationally determined minimum hourly wage. The lower level would be given enough time to work out a method that satisfies entitlements determined at the higher level, but it would nonetheless have to work one out. The standard set at the higher level would be the one that the lower level must achieve. The process is illustrated in Figure 1. In some circumstances, the policy framer and the lead agency may be the same entities. In some circumstances, the agencies of detail might be offshoots or formal subsidiaries of the lead agency. Results would be evaluated and ideas generated with a view to finding ways to deal with novel problems (or the same problem in different contexts). 
Crucially, such an approach must be designed to account for power. That is the key aim of the "directed" in "directed devolution." In whatever way the responsibilities are divided between the central agency and the agency of detail, it must be done such that it does not reduce the power of those whom regulation is meant to protect, i.e., by allowing their voices to be swamped by those with greater resources or by allowing their interests to be defined off the agenda (Bachrach \& Baratz, 1970; Nienhüser, 2008) . Centralization of decision-making is often seen as a way of increasing the power of labour vis-à-vis capital, and decentralization as a means of increasing the real power of capital (Katz, 1993). Regulation of work is typically aimed at protecting the most vulnerable elements of labour. So devolution of decision-making in itself can, if handled poorly, worsen the situation of those people that regulation is meant to protect. Directed devolution, by tightly constraining the room to manoeuvre of those at the more decentralized level, should minimize the likelihood of a power shift against the most vulnerable. At the same time, it should still allow some flexibility to account for differences in situation-specific circumstances.

Directed devolution is thus a specific form of institutional experimentation. While Murray et al. (2020, p. 142) refer to how experimentation can be a "transitional strategy" to explore alternatives, this particular model emphasizes it as both a flexible strategy and a learning strategy that enables actors to learn from the experiments of other actors. 
To see how the lower level might enact a minimum wage for workers not covered by a traditional hourly wage model, we can turn to the example of the road passenger transport industry in New York. In 2019 New York State already had a minimum wage that was high by American (but not international) standards: USD 15 per hour in New York City itself (and less outside the city). The arrival of "rideshare" corporations Uber and Lyft created major concern amongst taxi drivers who, if they owned the vehicle they drove, had paid large sums of money for a licence (a "medallion"). New York faced the same dilemma encountered by most major cities, where frequently the focus has been on the issue of whether "gig workers" are employees or independent contractors, and where adjudicators have at times expressed concern about the adequacies of the law. In an Australian case on the classification of "rideshare" drivers, the tribunal observed it might be that notions about what was necessary for an employment relationship to be established "are outmoded in some senses and are no longer reflective of our current economic circumstances." ${ }^{1}$ The judge in an American case commented that Uber and Lyft "present a novel form of business that did not exist at all ten years ago" and added, "With time, these businesses may give rise to new conceptions of employment status." ${ }^{2}$ In both cases, the non-employee status of the workers was reaffirmed-but in both cases, the adjudicators made clear that their decisions were based on the law as it stood, not on the law as it should be-once lawmakers work out what they actually want to do.

\footnotetext{
1 [2017] FWC 6610 (21 December 2017), at [66].

${ }^{2}$ Razak v. Uber Technologies Inc., U.S. District Court for the Eastern District of Pennsylvania, Case No. 2:16cv-00573, p. 25.
} 
In New York, as in many other jurisdictions, the value of licences plummeted with the entry of "rideshare" firms, and many drivers faced financial ruin due to stranded assets and falling incomes as low-priced competition undercut taxi fares. There was also extensive concern for the incomes of the Uber and Lyft drivers themselves; over time their incomes fell as the corporations tightened their budgets. Yet regulating hourly pay was very difficult for either taxi drivers or "rideshare" drivers, as payment was from individual customers and was output-based, being derived primarily from distance travelled, not hours worked. Moreover, much of the drivers' time was spent between jobs, either sitting in line-ups or driving around waiting for a job to appear. How could any regulation take this situation into account? Rather than focusing on how "rideshare" drivers could be reclassified as employees, New York focused on finding an equivalent for contractors of the hourly minimum wage.

After extensive consultation (though not consensus), policy-makers came up with a solution that involved setting a minimum charge based on what an equivalent hourly minimum wage would be after taking into account the time spent waiting between paying jobs as well as the value of other benefits, such as leave (International Transport Forum, 2019). A "utilisation rate" was calculated, based on detailed research by Parrott and Reich (2018), and used to convert hourly standards into a type of piece rate. It was based on research into time utilization by drivers. On implementation, it was immediately and unsuccessfully challenged in the courts by Lyft, but not Uber, as drivers for the former in practice had a higher utilization rate than those for the latter, and so it would be a heavier financial burden 
on Lyft (AFP, 2019). The key thing is that it was a highly innovative attempt to convert a high-level time-based minimum standard into a practical solution that took into account the specific circumstances of the sector.

This solution, though in some ways brilliant, was specific to that sector and could not be readily applied to the rest of the gig economy. Yet it was quite striking in its idea that regulators and parties with deep experience and knowledge of the particular sector would be in the best position to work out solutions specific to that sector. The experience was also quite isolated. Most local regulators, if not required to find a way to implement an entitlement, are unlikely to look for one because the ability of industry to capture regulators would potentially prevent any action from taking place if there was no legislative obligation for action. Rideshare firms have themselves shown this to be the case (Borkholder et al., 2018).

The New York passenger transport model may be relevant to other jurisdictions in relation to passenger transport, but it could need modification to suit local circumstances (utilization rates may vary substantially between locations) and could be unusable for activities outside passenger transport (a "fare" has a different meaning or none at all to a care worker or a food courier). A law that specified precisely the entitlements for workers defined as nonemployees would be very hard to draft. One that broadened the definition of employees 
would solve part of the problem, but would not solve it for workers who remained outside the definition.

Multi-Level Regulation Alternatives

Directed devolution is a form of multi-level policy-making. To understand its particular institutional form, its strengths and weaknesses, we will consider various historical forms of multi-level regulation. Multi-level regulation is not new, and identifying the right "balance between the top-down and the bottom-up" has been found to be quite "fruitful" for dealing with public policy problems (Ferlie et al., 2011, p. 322).

Obviously similar is the concept of subsidiarity. It is seen as originating in Roman Catholic social thought and "means that government should be as close as possible to the governed" (Kamarck, 2000, p. 240). It was applied in the context of the European Union (Franzese \& Hays, 2006). It signified the "preserving [of] substantial space for separate domestic political processes," with an example being the World Trade Organization "allowing domestic politics to sometimes depart from international" (Keohane \& Joseph S. Nye, 2000, pp. 37-38). The European Union project, to some extent reliant on the concept of subsidiarity, was originally supported by many as a means of achieving social objectives, yet most of the key institutions were captured by "neoliberal" interests. Meanwhile, voters at the local level 
were alienated from decisions at higher levels, an alienation that ultimately favoured the rise of populist, anti-market and perhaps quasi-fascist politics (Walby, 2018).

Directed devolution is a more tightly integrated form of regulation than is subsidiarity. In the former, legal obligations and entitlements apply at both levels. While the concept of subsidiarity is itself contested (Hecke, 2003), it ultimately provides the lower level with discretion, if decision-makers at that level feel the need, to depart from the standards applied at the higher level, standards that are often really principles or guidelines for the lower level.

ILO Conventions are a mechanism for multi-level regulation, similar to subsidiarity, but again lower-level compliance is voluntary. Countries can decide whether or not to ratify a convention, and then what legislation shall contain. Moreover, the conventions themselves usually specify obligations that are expressed as principles only. While some conventions specify more explicit rights (such as those on freedom of association and rights to collective bargaining), the great latitude available to countries in choosing whether and how they implement a convention means that adherence is varied and very incomplete (Hartlapp, 2007).

Another, and quite different, international example of multi-level regulation was the Accord on Fire and Building Safety in Bangladesh. The Accord was established in response to the deadly collapse of the Rana Plaza building that housed factories for over 1000 workers. 
It imposed legal obligations on lead brands and local factories. It only covered safety, not pay and conditions, but it required lead brands to set up audit processes to ensure that Bangladeshi factories comply with safety standards, either by forcing them to remediate or by removing them from the supply chain (Reinecke \& Docherty, 2015). The ILO chaired the oversight committee. The existence of legal obligations at the lower level (in this case, on the firm through the audit process) was central to the effectiveness of the Accord, unlike many other instances of voluntary codes of conduct or corporate social responsibility (Harpur, 2006). The fixed-term (five year) lifespan of the Accord has become a problem, specifically uncertainties about the future of regulation in this area due to political opposition by local employers and the Bangladesh government (BDApparelNews Desk, 2019; UNI Global Union, 2019).

A form of multi-level regulation more like directed devolution can be seen in occupational health and safety (OHS) regulation in Australia and New Zealand. National standards set a tight framework within which most Australian states and the government of New Zealand legislate. In essence, this legislation imposes obligations on employers to ensure a safe workplace-though, crucially, the relevant concept is actually a "person conducting a business or undertaking" (PCBU). In other words, contractors have the same protections as do employees, and PCBUs are responsible for the safety of both. That said, in many areas the detailed elucidation of safety standards (How wide should a particular piece of gasket insulation be? What form of guard must be used on a specific machine?) is too complex for national regulation, and instead legislation imposes obligations on individual employers to establish certain procedures (health and safety committees or officers) to ensure that 
appropriate safety standards are in effect in each workplace. In effect, each organization is forced to take a risk management approach to safety. The lower level is obliged to design workplace regulations (practices) to enact the standards set at the state (effectively national) level.

Australian industrial "awards" provide another illustration, though the form and content of "direction" varies over time and by issue (Peetz, 2020). Typically, a "test case" by a tribunal (currently the Fair Work Commission or FWC) established a standard that would be applied, sometimes with minor local variations, through awards covering specific industries or occupations. Inter-award variation declined over time in the face of pressure for less complexity. The people making awards were in the same institution as those determining the test cases, and sometimes awards were set by the same people who set the test case standards. The FWC showed a limitation shared by both higher and lower levels, with successive conservative governments seen as "stacking" appointments to the tribunal with appointees sympathetic to employers (Karp, 2018).

For the issues discussed here, perhaps the most relevant example from that country's industrial system was the Road Safety Regulation Tribunal (RSRT), a specialized, legislativelyestablished offshoot of the FWC. This tribunal was an attempt to apply what were in effect minimum wage standards to contractors, specifically owner-drivers of trucks. The RSRT sought to establish minimum piece rates for long-distance truck drivers delivering freight between varying locations. The rates took into account the time normally taken to drive such distances, thereby seeking both to achieve the equivalent of minimum hourly pay for 
contractor truck drivers and to increase incentives for safe practices (the rates of pay being described by unions as "safe rates"). It heard evidence from competing parties over a long period. Its weakness was political. It faced a concerted campaign by a conservative national government and by the core corporations that benefited from low-cost owner-driving. The campaign was assisted by opposition from many owner-drivers themselves, the intended beneficiaries. They opposed the minimum rates because of the RSRT's failure to take the "backload problem" into account. The "safe rates," while adequately compensating for the major long-distance hauls, did not allow for the situation of the much smaller "backloads" that drivers would take back to their home base at cheaper rates, but which were important to their financial viability. It was essential for the RSRT to take these local circumstances fully into account, but it did not devise a system that would. And it needed to take power into account. Taking advantage of this campaign, the conservative government abolished the RSRT, and a worker challenge to the power of core corporations collapsed.

Another Australian example of multi-level regulation illustrates a quite different way not to do devolution. The move to "enterprise bargaining" from 1991, by which wage determination was decentralized from national tribunal-based determination to bargaining between unions and individual employers, was certainly an instance of devolution. Bargaining at the enterprise level was constrained, to varying degrees, by the minimum standards established in awards. However, this move radically shifted the balance of power toward management and away from workers. In effect, it failed to adequately take power into account. A move from tribunal-based awards to direct bargaining between unions and employers would have probably brought about greater allowance for local circumstances, 
but the simultaneous forced move from multi-employer to single-employer bargaining weakened unions critically because they had relied on their collective strength as a countervailing power to employers. Australia's union movement was the only one in the OECD to support decentralization in bargaining (Katz, 1993). Since then, progress in reducing the gender pay gap has halted, and inequality has widened (Stewart, Stanford, \& Hardy, 2018). A shift from awards to bargaining, without the shift in bargaining level, would have simply made Australia's system consistent with the situation in many other OECD countries. This example shows that directed devolution and decentralization are not the same thing, and that directed devolution needs to be implemented in a way that recognizes the reality of the distribution of power and avoids undermining the power of workers.

This discussion of forms of multi-level regulation also shows that, while it is good to experiment, actors and policy-makers need to have long-term strategies, including plans to make mechanisms permanent if appropriate (and to avoid, if possible, the dangers of temporary or fixed-term arrangements). They also need to be careful in the processes of selecting institutional members, while being prepared to deal with powerful opposition, at both higher and lower levels, from well-organized and well-resourced interests. 
The examples discussed above suggest not only some of the problems to be avoided but also some criteria that we can use to determine where directed devolution may be a useful approach to policy.

Directed devolution can be useful where general principles can be determined, but there are complications with implementation. The general principles are determined at the national level, and the complications with implementation are sorted out at the lower level.

Directed devolution is useful where establishing enforceable general principles is important, and it can make a real difference. It is useful in such situations when circumstances vary considerably between organizations or industries, such as in payment systems or methods of generating surplus, where these factors can affect how a standard should be expressed. The "devolution" part of "directed devolution" is aimed at capturing the benefits of flexibility to respond to the uncertain effects of disruption, and to learn from the many policy experiments that inevitably occur.

Finally, directed devolution is appropriate where devolution of matters of detail can be achieved without losing enforceability, and where some method can be found to do so without shifting power away from those with less power. 
Let us now revisit and elaborate on how this principle of directed devolution can be applied in the platform economy. Standards of minimum pay would be established nationally, that is, employment standards for workers not employees, and then it would be left to tribunals or agencies ("agencies of detail") to determine how the standards apply in particular sectors (outside conventional employment). Framework legislation would set out a legally-binding requirement, for example that all workers are entitled to a minimum income of a certain amount, to certain conditions of employment and to collective bargaining rights ("standards"). It would establish agencies or tribunals to deal with implementation of this prescriptive principle in various contexts. Personnel might partly overlap between higher and lower levels. The implementation of those minimum conditions in each relevant context would be suspended until that agency or tribunal makes a decision in that context.

A subsidiary body - an "agency of detail" - would make a decision, based on evidence presented to it. Those minimum standards set by the higher level would (to the extent that they are related to matters outside the conventional employment relationship) not come into effect until a decision was made by an agency of detail. By setting at a higher level the obligations that apply, the power relationship is, to an extent, reset. Working out at a lower level the detailed obligations on capital and labour enables the detailed nuances to be taken into account. There would be no need for the agency to determine the standard itself, which would have already been set at a higher level. The agency is there to work out how to make it work. 
The agency could deal with a general case for implementation of the relevant standards, following a request by one or more parties (e.g., a union or other worker association), or in response to a case prosecuted by an aggrieved individual. The agency would hear the evidence from all sides on the practical aspects of how to implement the standards in that particular context. If it were a specific case on behalf of an individual-who asserts that his or her rights to the higher-level standards have not been upheld-the mechanics may be slightly different from the general case. Such a situation would still end up with both sides presenting evidence on the general practicality of various solutions and the best means of achieving them. In deciding the sequence of cases, priority should be given to those where the workers involved are in a potentially vulnerable situation, according to news stories, reports, investigations or initial submitted evidence.

Directed devolution is not a substitute for specific regulatory interventions in the platform economy, for example to enable proper classification of workers as employees vis-à-vis contractors. There is nothing in the directed devolution model that would undermine the rationale for reforms like the $\mathrm{AB} 5$ legislation in California. It is a complement, not a substitute, for such reforms; it is a recognition that the latter have limitations and, as such, is an effort to address those limitations. To the extent, however, that a directed devolution approach could make the employee-contractor distinction less important, it would move us closer to the "universal work relation" framework advocated by Countouris (2019) (and canvassed by Stewart \& Stanford, 2017). 


\section{Conclusion}

Disruption caused by the logic of modern capitalism and the processes of technological development has torn apart the "web of rules" that protected workers in the past. In its place has arisen a "patchwork of rules," as actors have engaged in institutional experimentation to try to recover lost ground. This patchwork, by definition, provides uneven coverage, and actors should learn from the successes and failures of their various experiments, even those policy-makers who wish to protect workers from the potential for exploitation.

Sympathetic policy-makers need institutional forms that can respond to the innovation that created the disruption, thus enabling them to protect the interests of the vulnerable who are their putative concern, and making possible innovative policy responses whose lessons will be learned and generalized. Directed devolution is one such form. It means legal entitlements or obligations are set at a higher level, and then a lower level is required to determine the detailed implementation of that standard with a view to protecting the affected workers' interests. There may be constitutional issues to deal with in specific national contexts, but they would be manageable (in Australia, for example, by use of the "corporations power" in the constitution). It is a model that has potential applications elsewhere in sectors subjected to digital disruption, such as the intrusion of decision-making algorithms into human resource management and consultation on digital technological change, but these are matters for other investigations. In the meantime, the affected workers will be protected essentially through those processes that have always mattered in 
assessing and addressing power: building collective organization; coordinating knowledgetransfer; anticipating the mobilization of counter interests; constructing viable alliances; ensuring that workers have the resources needed to participate (for example, to present evidence to lower-level agencies); and developing thoughtful strategy in response. But traditional power-building tools must be supplemented with institutional arrangements that can take into account nuanced and complex circumstances and the need for actors and organizations to learn. 


\section{References}

AFP. (2019). Judge rules Lyft must follow New York rules for driver minimum wage. Business Times.

Alkhatib, Ali, Bernstein, Michael S., \& Levi, Margaret. (2017). Examining Crowd Work and Gig Work Through The Historical Lens of Piecework. Paper presented at the CHI'17 Proceedings of the $2017 \mathrm{CHI}$ Conference on Human Factors in Computing Systems, Denver, CO.

Arntz, Melanie, Gregory, Terry, \& Zierahn, Ulrich. (2016). The Risk of Automation for Jobs in OECD Countries: A Comparative Analysis OECD Social, Employment and Migration Working Papers No 189. Paris: Organisation for Economic Cooperation and Development.

Bachrach, Peter, \& Baratz, Morton S. (1970). Power and Poverty: Theory and practice. New York: Oxford University Press.

BDApparelNews Desk. (2019, 5 February). Bangladesh's factories must never become death traps again: HRW. BDApparel News. Retrieved from https://www.bdapparelnews.com/Bangladeshs-factories-must-never-becomedeath-traps-again-HRW/270

Berg, Janine. (2016). Income security in the on-demand economy: Findings and policy lessons from a survey of crowdworkers. Geneva: Inclusive Labour Markets, Labour Relations and Working Conditions Branch, International Labour Office.

Borkholder, Joy, Montgomery, Mariah, Chen, Miya Saika, \& Smith, Rebecca. (2018). Uber State Interference: How Transportation Network Companies Buy, Bully, and Bamboozle Their Way To Deregulation. New York: National Employment Law Project and Partnership for Working Families.

Chartered Institute of Personnel and Development. (2017). To gig or not to gig? Stories from the modern economy. London: CIPD.

Christensen, Clayton M. (1997). The Innovator's Dilemma: When new technollogies cause great firms to fail. Boston: Harvard Business Review Press.

Countouris, Nicola. (2019). Defining and regulating work relations for the future of work. Geneva: Governance and Tripartism Department, International Labour Office.

De Stefano, Valerio. (2016). The rise of the «just-in-time workforce»: On-demand work, crowdwork and labour protection in the «gig-economy» Conditions of Work and Employment Series No. 71. Geneva: International Labour Office.

De Stefano, Valerio. (2018). Platform work and labour protection. Flexibility is not enough. Regulating for Globalization: Trade, Labor and EU Law Perspectives: Wolters Kluwer.

Dubal, Veena. (2019a). AB5: Regulating the Gig Economy is Good for Workers and Democracy. Expert Forum: Law and Policy analysis. from https://www.acslaw.org/expertforum/ab5-regulating-the-gig-economy-is-good-forworkers-and-democracy/

Dubal, Veena. (2019b). The Digitalization of Day Labor as Gig Work. On Labor.

Dunlop, John T. (1958). Industrial Relations Systems. New York: Holt. 
Ferlie, Ewan, FitzGerald, Louise, Dopson, Sue, McGivern, Gerry, \& Bennett, Chris. (2011). Public policy networks and 'wicked problems': A nascent solution? Public Administration, 89(2), 307-324.

Forsyth, Anthony. (2016). Victorian Inquiry into the Labour Hire Industry and Insecure Work: Final Report. Melbourne: Industrial Relations Victoria, Department of Economic Development, Jobs, Transport \& Resources.

Franzese, Robert J. Jr, \& Hays, Jude C. (2006). Strategic Interaction among EU Governments in Active Labor Market Policy-making: Subsidiarity and Policy Coordination under the European Employment Strategy. European Union Politics, 7(2), 167-189.

Frey, Carl Benedikt, \& Osborne, Michael A. (2013). The future of employment: How susceptible are jobs to computerisation? Oxford: Department of Engineering Science, University of Oxford,.

Gans, Joshua. (2016). The Disruption Dilemma Cambridge, MA: MIT Press.

Harpur, Paul. (2006). Regulating Multi-National Corporations Through State-Based Laws: Problems with Enforcing Human Rights Under The Alien Tort Statute. Australian International Law Journal, 13, 233-246.

Hartlapp, Miriam. (2007). On Enforcement, Management and Persuasion: Different Logics of Implementation Policy in the EU and the ILO. Journal of Common Market Studies, 45(3), 653-674.

Head, Brian W. (2008). Wicked Problems in Public Policy. Public Policy, 3(2), 101-118.

Hecke, Steven van. (2003). The principle of subsidiarity: Ten years of application in the European Union. Regional and Federal Studies, 13(1), 55-80.

Holmes, Allan, Cary, Peter, Yerardi, Joe, \& Zubak-Skees, Chris. (2019). Did billionaires pay off Repubicans for passing the Trump tax bill? Trump's Tax Cuts. Washington DC: Centre for Public Integrity.

International Transport Forum. (2019). Regulating App-Based Mobility Services. Paris: Organisation for Economic Cooperation and Development.

James, Natalie. (2020). Report of the Inquiry into the Victorian On-Demand Workforce: Genuine Choice, Certainty, Fair Conduct. Melbourne: Industrial Relatuions Victoria.

Johnston, Hannah, \& Land-Kazlauskas, Chris. (2018). Organizing On-Demand: Representation, Voice, and Collective Bargaining in the Gig Economy Conditions of Work and Employment Series No. 94 Geneva: Inclusive Labour Markets, Labour Relations and Working Conditions Branch, International Labour Office.

Kalleberg, Arne L. (2018). Precarious Lives: Job Insecurity and Well-being in Rich Democracies. Cambridge: Polity.

Kamarck, Elaine Ciulla. (2000). Globalization and Public Administration Reform. In Joseph S. Nye Jr. \& John D. Donahue (Eds.), Governance in a Globalizing World (pp. 229-252). Cambridge, MA: Brookings.

Karp, Paul. (2018, 7 December). Coalition stacking Fair Work Commission with mates, Labor says. Guardian. Retrieved from https://www.theguardian.com/australianews/2018/dec/07/coalition-stacking-fair-work-commission-with-mates-labor-says

Katz, Harry Charles. (1993). The Decentralisation of Collective Bargaining: A Literature Review and Theoretical Analysis. Industrial and Labor Relations Review, 47(1), 3-22. 
Keohane, Robert O., \& Joseph S. Nye, Jr. (2000). Introduction. In Joseph S. Nye Jr. \& John D. Donahue (Eds.), Governance in a Globalizing World (pp. 1-44). Cambridge, MA: Brookings.

Kerr, Clark, \& Siegal, Abraham. (1955). The structuring of the labor force in industrial society: New dimensions and new questions. Industrial and Labor Relations Review, 8(2), 151-168.

Lepanjuuri, Katriina, Wishart, Robert, \& Cornick, Peter. (2018). The Characteristics of Those in the Gig Economy. London: Department for Business, Energy \& Industrial Strategy.

May, Robyn. (2014). An Investigation of the Casualisation of Academic Work in Australia. (PhD doctoral thesis), Griffith University, Brisbane.

Meil, Pamela, \& Kirov, Vassil. (2017). Policy Implications of Virtual Work: Springer.

Minter, Kate. (2017). Negotiating labour standards in the gig economy: Airtasker and Unions New South Wales. Economic and Labour Relations Review, 28(3), 438-454.

Murray, Gregor, Levesque, Christian, Morgan, Glenn, \& Roby, Nicolas. (2020). Disruption and re-regulation in work and employment: from organisational to institutional experimentation. Transfer, 26(2), 135-156.

Nienhüser, Werner. (2008). Resource Dependence Theory - How Well Does It Explain Behavior of Organizations? Management Revue, 19(1+2), 9-32.

O'Neill, Cathy. (2016). Weapons of Math Destruction: How Big Data Increases Inequality and Threatens Democracy. New York: Crown Pubishing Group.

Parrott, James A, \& Reich, Michael. (2018). An Earnings Standard for New York City's Appbased Drivers: Economic Analysis and Policy Assessment Report prepared for the New York City Taxi and Limousine Commission. New York: The New School, Center for New York City Affairs.

Peetz, David. (2018). The Operation of the Queensland Workers' Compensation Scheme Report of the Second Five Yearly Review of the Scheme. Brisbane: Parliament of Queensland.

Peetz, David. (2019). The Realities and Futures of Work. Canberra: The Australian National University Press.

Peetz, David. (2020). Awards and collective bargaining in Australia: what do they do, and are they relevant to New Zealand? New Zealand Journal of Employment Relations, 44(3), 58-75.

Poulantzas, Nicos. (1980). State, Power, and Socialism. London: Verso.

Pressman, Jeffrey L, \& Wildavsky, Aaron. (1973). Implementation: How Great Expectations in Washington are Dashed in Oakland; or Why It's Amazing that Federal Programs Work At All, This Being a Saga of the Economic Development Administration as Told by Two Sympathetic Observers who Seek to Build Morals on a Foundation of Ruined Hopes. Berkeley: University of California Press.

Quiggin, John. (2010). Zombie Economics. New Jersey: Princeton University Press.

Rees, Gareth, \& Fielder, Sarah. (1992). The services economy, subcontracting and the new employment relations: Contract catering and cleaning. Work, Employment and Society, 6(3), 347-368.

Reinecke, Juliane, \& Docherty, Jimmy. (2015). After Rana Plaza: Building coalitional power for labour rights between consumption and production based actors. Organization, forthcoming. 
Rosenblat, Alex, \& Stark, Luke. (2016). Algorithmic labor and information asymmetries: A case study of Uber's drivers. International Journal of Communication, 10, 3758-3784.

Scholz, Trebor, \& Schneider, Nathan. (2017). Ours to Hack and to Own: The Rise Of Platform Cooperativism, A New Vision For The Future Of Work And A Fairer Internet. New York: OR Books.

Smith, Aaron. (2016). Gig work, online selling and home sharing: Pew Research Center.

Stewart, Andrew, \& McCrystal, Shae. (2019). Labour Regulation and the Great Divide: Does the Gig Economy Require a New Category of Worker? Australian Journal of Labour Law, 32, 4-22.

Stewart, Andrew, \& Stanford, Jim. (2017). Regulating work in the gig economy: What are the options? Economic and Labour Relations Review, 28(3), 1-18.

Stewart, Andrew, Stanford, Jim, \& Hardy, Tess (Eds.). (2018). The Wages Crisis in Austraia: What it is and What to do About it. Adelaide: University of Adelaide Press.

Stone, Katherine Van Wezel. (2015). Green Shoots in the Labor Market: Cornucopia of Social Experiments. Comparative Labor Law \& Policy Journal, 36(2), 293-322.

Streeck, Wolfgang. (1987). The Uncertainties of Management and the Management of Uncertainty. Work, Employment and Society, 1(2), 281-308.

UNI Global Union. (2019, 24 April). Six Years after Rana Plaza: Remembering What was Lost and Protecting the Progress That Has Been Made. News. Retrieved from www.uniglobalunion.org/news/six-years-after-rana-plaza-remembering-what-waslost-and-protecting-progress-has-been-made

Unions New South Wales. (2016). Innovation or Exploitation: Busting the Airtasker Myth. Sydney: Unions NSW.

Veen, Alex, Barratt, Tom, \& Goods, Caleb. (2019). Platform-Capital's 'App-etite' for control: A labour process analysis of food-delivery work in Australia. Work, Employment and Society. doi: DOI: 10.1177/0950017019836911

Walby, Sylvia. (2018). Is Europe Cascading into Fascism? Addressing Key Concepts including Gender and Violence. Politics and Governance, 6(3), 67-77.

Weil, David. (2014). The Fissured Workplace: Why Work Became So Bad for So Many and What Can Be Done to Improve It. Cambridge: Harvard University Press.

Wood, Alex. J., Graham, Mark, Lehdonvirta, Vili, \& Hjorth, Isis. (2018). Good gig, bad gig: autonomy and algorithmic control in the global gig economy. Work, Employment and Society, 33(1), 56-75. doi: 0950017018785616

Woodcock, Jamie, \& Graham, Mark. (2020). The Gig Economy: A Critical Introduction. Cambridge: Polity.

Wright, Chris F., Wood, Alex J., Trevor, Jonathan, McLaughlin, Colm, Huang, Wei, Harney, Brian, Geelan, Torsten, et al. (2019). Towards a new web of rules: An international review of institutional experimentation to strengthen employment protections. Employee Relations, 41(2), 313-330. doi: doi.org/10.1108/ER-10-2018-0259 
S1-16-19

4 octobre 2020 - derniere version

7781 mots

RevPF

Figure 1. Steps in Directed Devolution

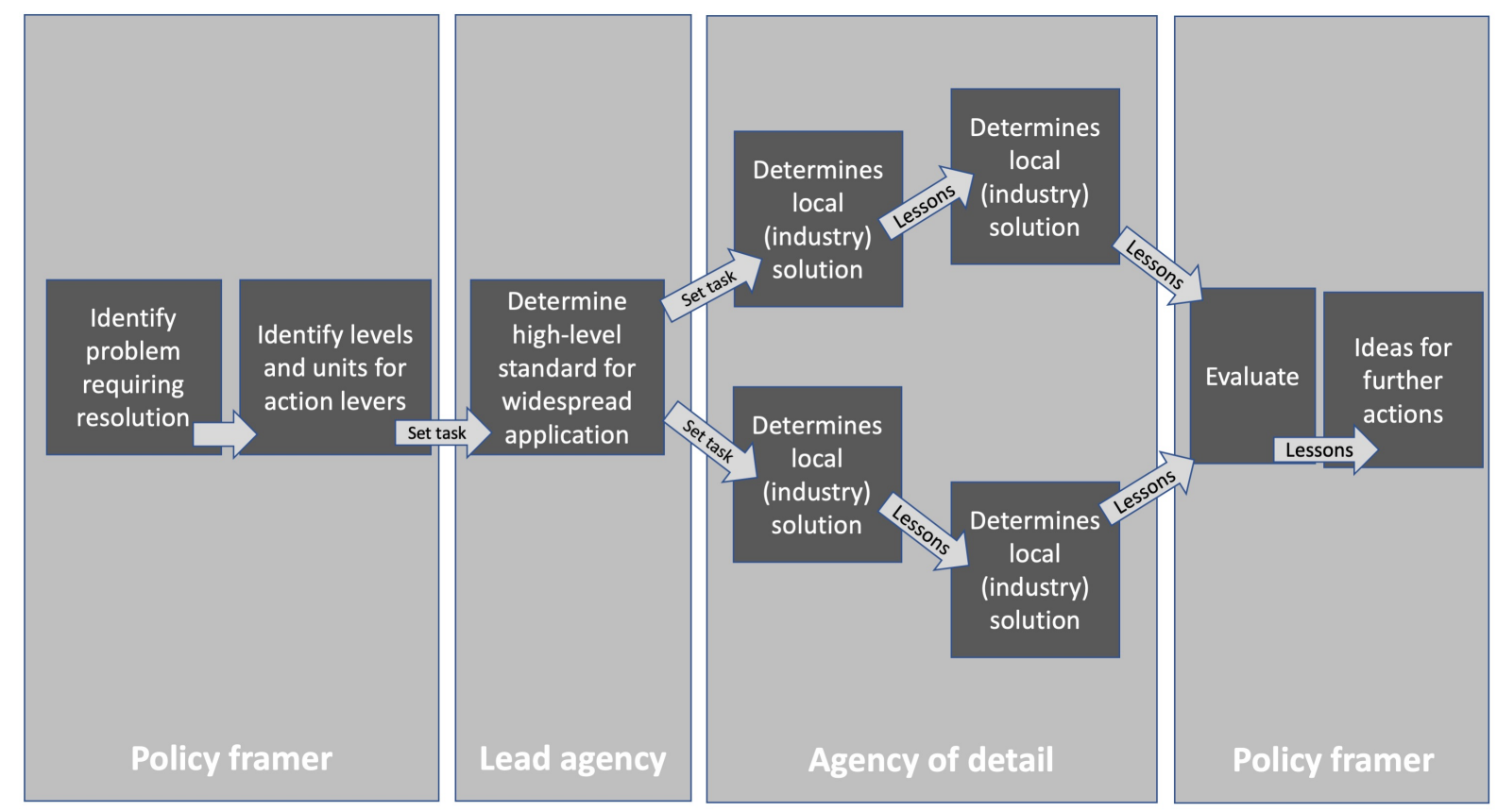

